\section{A CASE OF STATUS.EPILEPTICUS WITH AN UNUSUALLY LARGE NUMBER OF CONVULSIONS}

\author{
S. A. SNITTH, M.D. \\ LINCOLN, ILL.
}

Patient.-Delia N., a girl, white, aged $8 \frac{1}{2}$, was admitted to the Lincoln State School and Colony Jan. 29, 1912. Family history shows both mother and father and grandparents on both sides to be living and well. Hrothers and sisters of the patient are living and well. She was the fourth born of five children, weighing 9 pounds at birth, full term. It was noted at birth that she had a nevus covering all of the right side of the body and a small bloteh on the left thigh. It was also said that she had had a convulsion at the age of 1 year, the character of which is not known. No history could be ohtained as to the exact time when epileptic seizures commenced.

Hxamination.-The patient was a well-nourished child weighing about 58 pounds with a large reddish-purple discoloration of the skin on the entire right side with a small amount on the left thigh on its upper third. There was no deformity of the osseous structure. There were several scars on the child which she no doubt received during convulsions. There was a slight myocarditis and some tympanites. Eye reflexes were unuttainable on account of the constant tossing and restless. ness of the child during the examination. The patellar reflexes were exaggeratel on both sides, somewhat more on the left. Tento Achillis reflexes were much diminished. The Babinsk sign was absent on both sides. No definite information could be obtained, but it seemed as though the hearing and sight of the child were faulty. Gait was aflected due to a talipes equinovarus of both feet.

The child was unable to feed and dress herself, was very untidy in her habits and not attentive to the calls of Nature. She cried and fretted very much. The child's parents saic that she had been subject to a varied number of seizures for some time but they liad never kept any record, so they dirl not know how many she did have at times.

Clinical History.-She suffered one convulsion on the day of her admittanec, January 29; the next day six, and five on the 3lst. In the morning of February 1, eleven, and during the night forty-three. On February 2 , there were 461 , February 3 there were 573 , on February 4 there were 403 , on February 5, 158, the child dying at 10:15 p. m. The attucks were all of the grand-mat type, the child lying in a stupor between convulsions. She would respond to stimulation of the pain sense as on pricking the ear she would turn her head slightly, or on pinching the arm she would try to move it away. Bromids were administered from the time of her altuission in doses of $15 \mathrm{gr}$. of the triple bromids every four hours. On the afternoon of February 2 , she was anestheti\%ed three times with chloroform. During the surgical anesthesia she showed no convulsion, but as soon as the first evidence of the pupillary reaction occurred she would immediately sufler a terrific convulsion much worse than those previous. Morphin in 1/12 gr. doses hypodermically gave no results. Patient was malsle to take nourishment at any time. She had no involuntary passages of either urine or feces and it was nec. essary to catheterize her on the $3 d$, which was twenty-four hours after her severe seizures started. All other eflorts proved of no avail to induce urination. The temperature rose to $102 \mathrm{~F}$. during the afternoon of February 2 . At $8 \mathrm{p} . \mathrm{m}$., it was $104.8 \mathrm{~F}$. From then on it showed marked fluctuations until the evening of February 3 , when it returned to normal and stayed practically at normal, going to 100.0 a few hours before deatl. During seizures there would be marked rotation of the head to the right side with a nystagmus of both eyes with the long jerk toward the right side. The pupils would dilate markedly. She would perspire profusely, especially after a severe convulsion. On February 5 continuous normal saline per rectum was started and she absorbed 1 liter in four hours, after which she had a voluntary urination. Her urine examination on admission showed an occasional hyaline cast with no albumin. Catherized specimen during the convulsions showed twenty-four hour collection of only
6 ounces with an enormous number of hyaline casts and a large amount of albumin. A blood examination on February 4 showed normal number of red cells per eubic millimeter, large leukocytosis of 41,400 per c.c. The liemoglobin was 85 per cent. There was nothing unusual in the appearance of the red cells. A differential count of 100 white cells gave the polymorphonuclear neutrophils 85 per cent., the greater porcentage of whiclr were evidently young cells, being about in microns in diameter and the granules taking a deep stain, whereas the remaining cells were of normal size and staining much paler. The young cells averaged about five nuclei each, whereas the older cells averaged about two. Blood coagulated rapidly.

This case holds interest for the great number of grand-mal seizures that may occur in a case of status epilepticus, Spratling refers to LeRoy's case of 188 grand-mal seizures in twenty-four hours and to another case showing 1,000 seizures in three days, and also refers to cases ranging from 1,400 to 3,000 seizures ranging over a period of three weeks or more, which, he says, is too long a period for status epilepticus to persist, the average time being from twelve hours to three days.

My' case gives a total of 1,649 grand-mal scizures in $41 / 2$ days, with the largest number for any one twentyfour hours being 573 convulsions.

I wish to thank Dr. H. G. Hardt, Superintendent of the Lineoln State School and Colony, for his kindness in permitting me to report this case.

\section{EPITHELIOMA OF THE TONGUE}

WITH NO RECURRENCE NINE YEARS AFTER CLINIC.LL CURE WITII THE X-RAY

MARTIN F. ENGMAN, M.D.

Barnard Free Skin and Cancer IIospital ST. LouIs

This case is of interest as it had every clinical symptom of an epithelioma of the tongue. The clinical diagnosis was confirmed by several of the leading surgeons and dermatologists in this city, and in Chicago.

The patient appeared May 30, 1902, with a hard nodule on the left side of the tongue, situated in the anterior thircl. The nodule was raised about an eighth of an inch above the surface of the tongue, and extended into the substance for some distance. To the touch, it was hard, indurated, and resistunt. The center of the nodule was beginning to ulcerate, and there was some pain, especially when it came in contact with a hard substance. It had existed for several months, huving slowly increased in size.

The infiltration, situation and peculiar claracter of the lesion forced one to the diagnosis of epitheliama. No specimen was taken for microscopic examination, on account of the irritation that comes from such a course, and the possible opening of vessels for metastasis.

The patient refused operation, and on account of the location of the lesion in the anterior portion of the tongue, it was decided to attempt its destruetion with the $x$-ray. The following teclnic was employed: The tongue was drawn out aud held by the patient's right hand, which made it very necessible to treatment. An opening, larger than the nodule, was cut in a piece of lead foil, which was so placed that it covered the patient's face and hands, leaving exposed the. involved surface. The tube was then placed in gradually decreasing distances ranging from 5 to 2 inches of the nodule. Thirty exposures were given in all. The radiation was continued daily for from ten to fifteen minutes, until the mucous membrane was whitened, and reaction was obtained. This was allowed to subside, when another series of active radintion was begun. The last series was continued until the tumor presented a marked reaction, and all of the mucous membrane exposed was whitened. 
In two weeks after the last series, the whole area became very much infamed and painful, and continued so for a week, when a slough was formed, including the part exposed to the mdiations. This, according to the patient, came away ch. masse, as dead, necrotic tissue, leaving a henlthy-looking, granulated surface, which healed in a few weeks. After the last series of exposures, during the acute, inflammatory periol and slonghing, including the healing of the gramulated surfuce, the patient was at his cottage in Atlantic City; therefore I did not see him until he returned, in the fall, at which time the tongue had entirely recovered. The site of the former nodule was marked by a smooth, perfectly flexible, superficial cicatrix; in other words, the whole area seemed almost normal, exeept on a very eritieal examination.

I have seen the patient many times during the last nine years, and at present the tongue seems absolutely. well, the site of the former lesion being marked by a cicatricial line. To all clinienl appearances, the diagnosis was that of epithelioma, although, as stated above, it was thought wise not to confirm this by the excision of a piece for microscopic examinntion, but $I$ am absolutely convinced that the diagnosis of epithelioma was the proper one.

Although I lave had such a favorable result in this case, I certainly would not recommend the $x$-ray as a usual method of treatment in epithelioma of the tongue.

In the ase under discussion, the patient absolutely refused operation, and as the lesion was so favorably situated on the anterior portion of the tongue, near the edge, it seemed, under the circumstances, a favorable case for the rays. Therefore, on account of the nature of the lesion, rather prolonged exposures were given, at, a short distance, mitil a very decided reaction was obtained in each series.

If one should undertake the treatment of such a casc with the $x$-ray, I believe that the treatment should be as radical as possible. In other words, the exposures should be arranged so that a most decided reaction or burn would be produced.

412 Humboldt Building.

\section{MALICIOUS AMPU'TATION OF PENIS}

\section{R. I. Mubey, M.D., Aberdeex, S. Dak.}

History--J. C., a well-developed and vigorous man aged 25 , a railway firemun, a steady and industrious worker of fairly good hubits but not strictly temperate, land married a womau much older thm himself, who had twice before been unlmppily married. This couple had not been living very happily togeiner for some time; each occupied a separate part of the house, up to July 4, 1911, at which time there had been reconciliation and they had agreed to live together as man and wife; accordingly they had oceupied a common apartment on the night of July 4. About 4:00 a. m., July 5, the man was aroused by a terrific pain and a frightful hemorrlange, and he found himself in the middle of the floor holding onto a more or less completely amputated penis, the stump and wound bleding profusely. The major part of the organ was on the floor and the bed and the room were very bloody. He was alone, but cries for help brought a neighbor to his aid. The woman had taken a razor and with a sweeping cut had cut a circle around the root of the penis coming down and going wide into the skin and tissues of the scrotum turning under the penis some distance down on the serotum erossing the median raphe and extending the incision up the other side of the scrotum to the starting-place, making an elliptical incision of the most minute precision. After this the skin had been drawn down and out until it had been detached from the root of the penis for about 1 inch, at which place it had been cut square across leaving that much of the penis without a sign of skin. The woman, after completing the amputation, rushed to a plysician's residence and sent the doctor hurriedly to him, saying he was hurt.
First Operation.-The doctor put in some stitches in the skin, and a bandage around the stump to control the hemorrhage and sent the patient in to the hospital on the first train, where he arrived about 1:30 p. m. About 2 p. m. he was anesthetized and we started a rather unusual operation, which taxel all our ingenuity to devise a method by which we could save the stump and cover it with skin. We decided on $n$ two-step operation. First, by sliding the skin of the scrotum and pubes, we were able to cover it by bringing the skin together over the dorsum making a linear row of sutures down to the urethra, where we put in interrupted sutures, suturing the skin to the mucosa. The corpora cavernosa were closel with a mattress suture to control hemorrhage. Drainage was provided for, and a catlieter was fastened in place, and a sterile dressing applied.

The catheter remained in place for four or five days, at which time it was removed and left out as the patient had no further trouble about passing urine. The method of covering the denuded penis drew it down somewhat into the scrotum, and the patient was bothered very much with erections, which caused the skin to separnte slightly over the dorsum and necessitated a few more sutures about the tenth day. The progress was uneventful after this, and the healing was fine. When the wound was healed we still had the penis more or less buried in the scrotum which drew down on the penis and up on the testicles, producing more or less disagreeable symptoms, which we were able to relieve quite satisfactorily at the second operation.

Second Operation.-August 9, two methods were considered for freeing the penis and making a skin cover to go around the organ. First, two lateral incisions with skin enough to close underneath or a transverse incision sutured longitudinally underneath the stump. A combination of the methods to furnish skin to close a slight defect at the meatus was worked out and proved quite satisfactory; however, this mennt the stealing of much skin from the scrotum and the placing of all parts unider some tension. The most difficult part of the second operation was freeing the penis from the scrotum, and the hemorrhage which seemed to come from the penoscrotal union underneath was not alarming but interfered with such delicate work.

Course-Che result would have been all that conld have been expected except for a hematoma which upset part of our fine adjustment. Present condition shows a short penis, covered with skin, much wider and thicker than normal at the root; the patient says that it is enormously widened when in a state of erection, and that has been a very troublesome symptom. The patient consulted a noted surgeon in Chicngo who advised lim that he could graft on a penis, and that he would do it free of charge as a surgical curiosity. From the reputation of the surgeon consulted we do not doubt his ability to make good, providing the grafting material is forthcoming; and as no such material is available in these parts of the country, I have advised the patient to accept the generous offer of the Chicago specialist, but requested him to return and report on the results.

l'atient insists that he was chloroformed in his sleep. I suspected overindulgence in alcoholies, which $I$ have not been able to confirm.

\section{Therapeutics}

\section{BLEEIDERS}

Whether a patient should be classed as a hemophiliac or as an acejiclental or temporary bleeder depends ]argely on the age of the patient, his personal and family history. There is a large hereditary influence in true hemophilia. Blood-vessel causes are probably rare in the true hemophiliac, and the tendency to bleed seems to be due to an abnormality in the blood-plasma. Such abnormality may be almost permanent, as occurs in hemophilia, or temporary, as in those who show a sudden tendency to bleed. The lack of ability of the blood to 